\title{
Problematika Hukum Calon Tunggal dalam Pemilihan Kepala Daerah Serentak Tahun 2015
}

\author{
Maryam Nur Hidayati \\ Mahasiswa Fakultas Hukum Universitas Islam Indonesia \\ Jl. Taman Siswa No. 158 Yogyakarta \\ maryamhidayati@yahoo.com
}

\begin{abstract}
The legal issue on the single candidate of regional head has been initiated with the emergence of phenomenon of the single candidate of regional head in a number of regions in Indonesia. In reality, Law Number 8 of 2015 does not anticipate the existence of the candidate of regional head and to anticipate such condition, the Regulation of KPU No. 12 of 2015 regarding the postpone of the election of regional head is issued if there is only one pair of condidate in one region. The research studies the issues: first, the legal issue the single candidate of regional head in the election of the regional head is contemporaneous in 2015 in accordance with Regulation No. 8 of 2015; Second, the effort to cope with the single candidate of regional head in the following election of regional head. This is a qualitative research with the method of normativedescriptive approach that has been analyzed descriptively and processed using the literatures from the secondary data sources. The results of the research showed that first, the legal issue on the single candidate of regional head in the election of the regional head simultaneously occurred in 2015 is initiated with the legal solution from KPU with the issue of Regulation of KPU no. 12 of 2015 and the existence of the legal claim of judicial review to the Constitutional Court creating a number of legal implications. Second, the effort to prepare the next contemporaneous election of the regional head needs to be given a revision of Regulation No. 8 of 2015. This is as an effort to enforce the demoracy and to prioritize the people's rights in Indonesia.
\end{abstract}

Keywords: Legal issues, single candidate, election of regional head

\begin{abstract}
Abstrak
Problematika hukum calon tunggal kepala daerah diawali dengan munculnya fenomena calon tunggal kepala daerah di beberapa daerah di Indonesia. Dalam praktiknya, Undang-Undang Nomor 8 Tahun 2015 tidak mengantisipasi adanya calon tunggal kepala daerah dan untuk mengantisipasi kondisi tersebut, muncul Peraturan KPU No. 12 Tahun 2015 terkait penundaan pemilihan kepala daerah jika hanya terdapat satu pasangan calon dalam suatu daerah. Penelitian ini mengkaji permasalahan: pertama, problematika hukum calon tunggal kepala daerah dalam pemilihan kepala daerah secara serentak tahun 2015 berdasarkan UU No. 8 Tahun 2015; Kedua, upaya untuk mengatasi calon tunggal kepala daerah dalam pemilihan kepala daerah yang akan datang. Penelitian ini merupakan penelitian kualitatif, dengan metode pendekatan yuridis normatif, yang dianalisis secara deskriptif kualitatif serta diolah dengan cara studi pustaka dari sumber data sekunder. Hasil penelitian menyimpulkan, pertama, problematika hukum calon tunggal kepala daerah dalam pemilihan kepala daerah serentak di tahun 2015 diawali dengan solusi hukum yang berasal dari KPU dengan dikeluarkannya Peraturan KPU No. 12 Tahun 2015 dan adanya gugatan judicial review ke Mahkamah Konstitusi yang menimbulkan beberapa implikasi hukum. Kedua, upaya untuk mempersiapkan pemilihan kepala daerah serentak yang akan datang perlu segera dilakukan revisi UU No. 8 Tahun 2015. Hal demikian sebagai upaya menegakkan demokrasi dan mengedepankan hak-hak masyarakat Indonesia.
\end{abstract}

Kata kunci: Problematika hukum, calon tunggal, pemilihan kepala daerah 


\section{IEx Renaissance No. 1 VOL. 1 JANUARI 2016: 37 - 57}

\section{Pendahuluan}

Pemilihan kepala daerah (pilkada) merupakan agenda demokrasi untuk memilih kepala daerah yang diamanatkan oleh UUD NRI 1945. Berdasarkan Pasal 18 ayat (4) UUD NRI 1945, pemilihan kepala daerah dilakukan secara demokratis. Berdasarkan teori demokrasi yang dikemukakan Abraham Lincoln bahwa demokrasi adalah sistem pemerintahan dari rakyat, oleh rakyat, dan untuk rakyat (democracy is goverment of the people, by the people, for the people) yang kemudian dikenal sebagai demokrasi modern. ${ }^{1}$

Konstitusi mengamanatkan bahwa bentuk negara Indonesia merupakan Negara Kesatuan Republik Indonesia (NKRI) sebagaimana tercantum dalam Pasal 1 ayat (3) UUD NRI 1945. Negara Kesatuan Republik Indonesia menerapkan otonomi daerah, dimana negara terbagi-bagi menjadi berbagai provinsi dan kabupaten. Ketukan palu Pimpinan DPR ketika mengesahkan Undang-Undang No. 22 Tahun 1999 tentang Pemerintahan Daerah adalah dentuman awal hidupnya sistem desentralisasi dalam struktur ketetanegaraan Indonesia. Penerapan desentralisasi atau yang biasa disebut otonomi daerah, adalah nafas baru bagi setiap daerah untuk berkembang sesuai dengan cita-cita yang tidak tersampaikan pada rezim orde baru yang lalu. Otonomi daerah melepaskan beban ketergantungan dari kualitas sensitifitas pemerintahan pusat untuk bisa mendapatkan kesejahteraan yang adil dan merata. Konsep otonomi daerah ini kemudian memberikan konsekuensi tentang pengaturan mengenai pemerintahan daerah salah satunya adalah pemilihan kepala daerah.

Semangat pelaksanaan otonomi daerah ini, tentu juga menghasilkan konsekuensi hukum dalam relasinya dengan pilihan politik demokrasi di Indonesia. Pada masa setelah reformasi dikeluarkannya produk hukum terkait dengan pemerintahan daerah yakni Undang-Undang Nomor 22 Tahun 1999 serta Undang-Undang No. 32 Tahun 2004 tentang Pemerintahan Daerah. Kedua undang-undang tersebut memasukkan aturan pemilihan kepala daerah ke dalam materi muatan yang diatur. Kemudian, pada tahun politik 2014 dihasilkan produk hukum yang mengatur tersendiri mengenai pemilihan kepala daerah ke dalam bentuk undang-undang.

Diawali dengan disahkannya Undang-Undang No. 22 Tahun 2014 tentang Pemilihan Gubernur, Bupati, dan Walikota yang mengatur khusus mengenai pemilihan kepala daerah. Akan tetapi undang-undang tersebut mendapatkan penolakan yang luas oleh rakyat, hal ini karena dianggap proses pengambilan keputusan melalui Dewan Perwakilan Rakyat Daerah

${ }^{1}$ http://research.amikom.ac.id/index.php/SSI/article/view/6465 diakses pada tanggal 22 September 2015. 
tidak mencerminkan prinsip demokrasi. Pemerintah mengambil sikap dengan mengeluarkan Perppu No. 1 Tahun 2014 tentang Pemilihan Gubernur, Bupati, Walikota untuk mengembalikan prinsip demokrasi yang diinginkan masyarakat Indonesia. Terhadap Perppu No. 1 Tahun 2014 tersebut ditetapkan menjadi Undang-Undang No. 1 Tahun 2015.

Aturan hukum berikutnya yang dikeluarkan oleh legislatif dan pemerintah adalah Undang-Undang No. 8 Tahun 2015 yang merubah Undang-Undang No. 1 Tahun 2015 tentang Penetapan Peraturan Pemerintah Pengganti Undang-Undang No. 1 Tahun 2015 tentang Pemilihan Gubernur, Bupati, dan Walikota menjadi Undang-Undang. Beberapa materi muatan penting di dalam aturan hukum tersebut yang menjadi poin tambahan dalam pembahasan pemilihan kepala daerah yaitu mengenai pemilihan kepala daerah (pilkada) serentak, persyaratan calon peserta, serta penetapan calon peserta.

Terkait penetapan calon peserta terdapat beberapa hal yang menarik untuk diperhatikan. Bahwa terhadap kewenangan Komisi Pemilihan Umum baik di tingkat provinsi maupun kabupaten hanya dapat menetapkan paling sedikit 2 pasangan calon gubernur atau wakil gubernur maupun pasangan calon bupati atau wakil bupati. ${ }^{2}$ Ketentuan tersebut dinilai oleh banyak kalangan masyarakat sebagai aturan terburu-buru atau merupakan kekhilafan dari para legislator. Hal ini juga berimplikasi langsung dan menjurus pada permasalahan dalam pelaksanaan pemilihan kepala daerah yang dijadwalkan pada 9 Desember 2015.

Permasalahan pertama yang merupakan salah satu "pertanyaan besar" adalah akankah gagasan pemilihan kepala daerah secara serentak tidak dapat dilaksanakan di penghujung 2015? Hal ini didasarkan pada Peraturan KPU No. 12 Tahun 2015 tentang Perubahan Atas Peraturan Komisi Pemilihan Umum No. 9 Tahun 2015 tentang Pencalonan Pemilihan Gubernur Dan Wakil Gubernur, Bupati Dan Wakil Bupati, Dan/Atau Walikota Dan Wakil Walikota, dinyatakan bahwa Pasal 89 mengatur apabila pada masa akhir pendaftaran hingga dilakukannya perpanjangan masa pendaftaran pasangan calon hanya terdapat 1 pasangan calon mendaftar, maka KPU daerah menetapkan keputusan penundaan seluruh tahapan dan pemilihan diselenggarakan pada pemilihan serentak berikutnya. Hal ini juga diatur dalam Peraturan KPU No. 12 Tahun 2015, daerah yang memiliki calon kepala daerah kurang dari dua pasang harus menunda pelaksanaan hingga $2017 .^{3}$

Penundaan pelaksanaan pilkada bagi daerah-daerah yang memiliki calon tunggal tidak akan mewujudkan ide baru pilkada serentak. Laporan data terbaru terkait dengan

\footnotetext{
${ }^{2}$ Lihat Pasal 51 ayat (2) UU No. 8 Tahun 2015 dan Pasal 52 ayat (2) UU No. 8 Tahun 2015.

${ }^{3}$ Lihat Peraturan KPU No. 12 Tahun 2015
} 


\section{Lx Renaissance No. 1 VOL. 1 JANUARI 2016: 37 - 57}

pendaftaran calon kepala daerah telah dipastikan hanya tiga daerah yang memiliki calon tunggal. Komisioner KPU Ida Budhiati, pada 30 September 2015 menyampaikan bahwa ketiga daerah tersebut adalah Blitar Jawa Timur; Timor Tengah Utara Nusa Tenggara Timur; dan Tasikmalaya Jawa Barat. ${ }^{4}$ Meskipun hanya tersisa tiga daerah yang memiliki calon tunggal tidak menjadikan bahwa permasalahan yang timbul sudah terselesaikan. Diperlukan suatu konsep penyelesaian masalah untuk calon tunggal kepala daerah.

Permasalahan kedua yang muncul sebagai implikasi calon tunggal adalah mekanisme pemungutan suara bagi daerah yang memiliki calon tunggal. Effendi Ghazali mengajukan judicial review terhadap UU No. 8 Tahun 2015 terkait dengan adanya calon tunggal yang dapat menyebabkan penundaan pilkada. Mahkamah Konstitusi dalam putusannya memberikan persetujuan untuk dilakukannya referendum dalam mekanisme pemungutan suara bagi calon tunggal pemilihan kepala daerah melalui Putusan MK No. 100/PUU-XIII/2015. ${ }^{5}$ Kekhawatiran-kekhawatiran lain akan terus bermunculan mengingat aturan hukum UU No. 8 Tahun 2015 tidak memberikan solusi serta antisipasi terhadap permasalahan yang akan terjadi.

\section{Rumusan Masalah}

Berdasarkan uraian di atas, dirumuskan permasalahan sebagai berikut: Pertama, bagaimana problematika hukum calon tunggal kepala daerah dalam pemilihan kepada daerah serentak 2015 menurut Undang-Undang No. 8 Tahun 2015 tentang Pemilihan Gubernur, Bupati, dan Walikota? Kedua, bagaimana upaya untuk mengatasi adanya calon tunggal kepala daerah dalam pemilihan kepala daerah serentak yang akan datang?

\section{Tujuan Penelitian}

Adapun penelitian ini bertujuan untuk mengetahui: Pertama, problematika hukum calon tunggal kepala daerah dalam pemilihan kepada daerah serentak tahun 2015 menurut Undang-Undang No. 8 Tahun 2015 tentang Pemilihan Gubernur, Bupati, dan Walikota. Kedua, upaya untuk mengatasi adanya calon tunggal kepala daerah dalam pemilihan kepala daerah serentak yang akan datang.

${ }^{4}$ http://print.kompas.com/baca/2015/09/30/Kejar-Pilkada-2015\%2c-Tiga-Kabupaten-dengan-CalonTu, diakses 25 Oktober 2015

${ }^{5}$ Mahkamah Konstitusi, www.mahkamahkonstitusi.go.id 


\section{Metode Penelitian}

Jenis penelitian ini adalah penelitian kualitatif dengan metode pendekatan yuridis normatif melalui kajian peraturan perundang-undangan dan literatur yang berhubungan dengan masalah yang diteliti. Jenis data yang digunakan adalah data sekunder, yang terdiri atas bahan hukum primer, yakni peraturan perundang-undangan, bahan hukum skunder, dan bahan hukum tersier. Teknik pengolahan data adalah studi pustaka yang dianalisis secara deskriptif kualitatif.

\section{Hasil Penelitian dan Pembahasan}

\section{Problematika Hukum Calon Tunggal Kepala Daerah}

Pelaksanaan pemilihan kepala daerah merupakan conditio sine quanon dalam penyelenggaraan pemerintahan daerah yang demokratis. Peraturan perundang-undangan telah dibentuk untuk memberikan pengaturan terkait pelaksanaan pemilihan kepala daerah sesuai dengan amanat UUD perubahan kedua Pasal 18 ayat (4) UUD NRI 1945, yang menyatakan bahwa, "Gubernur, Bupati, dan Walikota masing-masing sebagai kepala pemerintahan daerah provinsi, kabupaten, dan kota dipilih secara demokratis." Pengertian frasa "dipilih secara demokratis" dalam Pasal 18 ayat (4) UUD 1945 tidak harus diartikan dipilih secara langsung oleh rakyat, tetapi dipilih secara tidak langsung pun dapat diartikan demokratis, sepanjang prosesnya demokratis. ${ }^{6}$ Hal tersebut juga dikuatkan melalui Putusan Mahkamah Konstitusi No. 72-73/PUU-II/2004 yang memberikan makna demokratis dalam pemilihan kepala daerah, bahwa pemilihan kepala daerah baik secara langsung maupun tidak langsung tetap konstitusional asalkan tetap berpedoman pada asas langsung, umum, bersih, jujur dan adil (luber judil) sebagaimana diamanatkan Pasal 22E UUD NRI 1945.

Aturan normatif yang mengatur mengenai pemilihan kepala daerah di 2015 setelah melalui perbaikan demi perbaikan, diatur dalam Undang-Undang No. 8 Tahun 2015 tentang Perubahan atas Undang-Undang No. 1 Tahun 2015 tentang Penetapan Peraturan Pemerintah Pengganti Undang-Undang No. 1 Tahun 2014 tentang Pemilihan Gubernur, Bupati, dan Walikota (UU No. 8 Tahun 2015).

UU No. 8 Tahun 2015 memberikan aturan terbaru mengenai pemilihan kepala daerah, yaitu penyelenggaraan pemilihan kepala daerah yang dilaksanakan secara serentak

${ }^{6}$ Ni'matul Huda, Dinamika Ketatanegaraan Indonesia dalam Putusan Mabkamah Konstitusi, FH UII Press, Yogyakarta, 2011, hlm. 189-190. 


\section{Lx Renaissance No. 1 VOL. 1 JANUARI 2016: 37 - 57}

di seluruh Indonesia. Hal tersebut dapat disimpulkan dari rumusan Pasal 3 ayat (1) UU No. 8 Tahun 2015 yang berbunyi bahwa, "Pemilihan dilaksanakan 5 (lima) tahun sekali secara serentak di seluruh wilayah Negara Kesatuan Republik Indonesia." Rencana pelaksanaan pemilihan kepala daerah secara serentak dengan bertahap di beberapa daerah yang di mulai pada 2015, 2017, 2018, 2020, 2022, dan nantinya akan dilakukan pemungutan suara serentak nasional dalam pemilihan kepala daerah di seluruh wilayah Negara Kesatuan Republik Indonesia pada tanggal dan bulan yang sama pada $2027 .^{7}$

Adapun dalam pemilihan kepala daerah serentak di 2015 kemarin diselenggarakan di 9 Provinsi, 36 Kota dan 224 Kabupaten yang mengikuti kontestasi pesta demokrasi di penghujung tahun yaitu pada 9 Desember 2015. ${ }^{8}$ Akan tetapi, setelah habis masa pendaftaran terdapat 11 daerah yang hanya terdapat satu pasangan calon, adapun daerah tersebut yakni, Kabupaten Asahan (Sumatra Utara), Kabupaten Serang (Banten), kabupaten Tasikmalaya (Jawa Barat), Kota Surabaya, Kabupaten Blitar, Kabupaten Pacitan, Purbalingga (Jawa Tengah), Minahasa Selatan, Timur Tengah Utara, Samarinda, dan Mataram. ${ }^{9}$ Bahkan terdapat satu daerah yang tidak memiliki calon sama sekali yaitu Kabupaten Bolaang Mongondow Timur. ${ }^{10}$

Berdasarkan rekomendasi Bawaslu, rapat pleno KPU memutuskan untuk memperpanjang waktu pendaftaran. ${ }^{11}$ Sehingga tersisa tujuh daerah yang masih memiliki calon tunggal, ke tujuh daerah tersebut adalah Kabupaten Tasikmalaya (Jabar), Kota Surabaya, Kabupaten Blitar, Kabupaten Pacitan (Jatim), Kota Mataram (NTB), Kota Samarinda (Kaltim), dan Kabupaten Timor Tengah Utara (NTT). ${ }^{12}$ Menindaklanjuti hal tersebut, KPU mengeluarkan Surat Edaran No. 449/KPU/VIII/2015 yang ditujukan kepada KPU daerah di tujuh daerah itu.Isinya, diberikan perpanjangan pendaftaran peserta pilkada mulai tanggal 1 dan berakhir 3 Agustus 2015. ${ }^{13}$

Namun, hingga hari terakhir perpanjangan pendaftaran pasangan calon pilkada serentak 2015, Senin (3/8), dari 269 daerah yang akan menggelar pilkada, di tujuh daerah kabupaten/kota hanya terdapat satu pasangan calon. Berdasarkan data Komisi Pemilihan

\footnotetext{
${ }^{7}$ Lihat dalam Pasal 201 UU No. 8 Tahun 2015

${ }^{8}$ Calon Tunggal, Perppu dan Kekosongan Hukum, Suara Komisi Pemilihan Umum, edisi IV Juli-Agustus 2015, http://www.kpu.go.id/koleksigambar/Revisi+Final+Majalah+Suara+KPU+Edisi+4.compressed_.pdf ${ }^{9} \mathrm{http}: / /$ nasional.republika.co.id/berita/nasional/politik/15/07/29/ns7nne313-kpu-ada-11-daerahmiliki-calon-tunggal diakses 15 Desember 2015

${ }^{10}$ Calon Tunggal, Perppu..., Ibid.

${ }^{11}$ Antisipasi Calon Tunggal, KPU Perpanjang Waktu Pendaftaran Calon Pilkada, wmw.voaindonesia.com diakses pada tanggal 15 Januari 2016.

${ }^{12 h t t p: / / j a t i m . m e t r o t v n e w s . c o m / r e a d / 2015 / 08 / 10 / 419568 / p i l k a d a-d i t u n d a-j i k a-d i-t u j u h-d a e r a h-~}$ tetap-hanya-calon-tunggal, diakses pada tanggal 15 Januari 2016.

13Polemik Calon Tungal Pilkada Serentak, Kompas Print, 23 Agustus 2015.
} 
Umum (KPU), hingga batas akhir pendaftaran pilkada hanya ada satu pasangan calon di Kabupaten Blitar, Kabupaten Pacitan, Kabupaten Tasikmalaya, Kabupaten Timor Tengah Utara, Kota Mataram, Kota Samarinda, dan Kota Surabaya. ${ }^{14}$

Presiden Joko Widodo membahas persoalan calon tunggal dan akhirnya dipilih opsi perpanjangan waktu pendaftaran tahap kedua mulai Minggu 9 Agustus hingga Selasa 11 Agustus. Hasil akhir pendaftaran calon peserta pilkada hanya tinggal empat daerah dengan calon tunggal pilkada. Daerah tersebut adalah Kabupaten Tasikmalaya, Kota Mataram, Kabupaten Timor Tengah Utara, dan Kabupaten Blitar. ${ }^{15}$ Akan tetapi, terhadap Kota Mataram, Panitia Pengawas Pemilu mengabulkan permohonan sengketa pasangan Salman dan Jana untuk menjadi pesaing pasangan petahana Abduh dan Mohan. Keadaan tersebut dilatarbelakangi oleh kisruh pengusungan calon dari Partai Golkar, yang pada akhirnya dinyatakan resmi bahwa kedua calon diusung oleh Partai Golkar. ${ }^{16}$ Ketiga daerah tersebut, selanjutnya akan melaksanakan pemilihan kepala daerah dengan satu pasangan calon saja, kemudian istilah yang muncul adalah calon tunggal kepala daerah. Berdasarkan fenomena calon tunggal tersebut selanjutnya muncul permasalahan hukum baru yang dihadapi oleh negara apabila dikaji lebih dalam dari segi normatifnya.

Salah satu hal menarik di dalam ketentuan UU No. 8 Tahun 2015 adalah secara das sollen, bahwa undang-undang menghendaki pemilihan kepala daerah yang diadakan serentak di tahun 2015 diharuskan memiliki minimal dua pasangan calon di masing-masing daerah. Hal ini berkaitan erat bahwa pemilihan umum maupun pemilihan kepala daerah merupakan suatu kontestasi politik dari beberapa pilihan calon yang diajukan. Ketentuan tersebut diatur di dalam Pasal 51 ayat (2) dan Pasal 52 ayat (2) UU No. 8 Tahun 2015. Ketentuan tersebut menyebutkan bahwa berita acara penetapan yang dibuat oleh KPUD harus menetapkan paling sedikit 2 pasangan calon kepala daerah. ${ }^{17}$ Sehingga sudah terbaca jelas bahwa setiap daerah harus memiliki calon kepala daerah paling sedikit dua pasangan calon. Akan tetapi, aturan di dalam UU Pilkada tidak memberikan kedudukan bagi daerah yang hanya memiliki satu pasangan calon kepala daerah.

Secara das sein, terdapat fenomena yang terjadi di masyarakat yaitu adanya calon tunggal dalam pemilihan kepala daerah. Adapun daerah tersebut adalah Kabupaten Tasikmalaya, Kota Mataram, Kabupaten Timor Tengah Utara, dan Kabupaten Blitar. Kondisi demikian menimbukan kekhawatiran secara nasional apabila merujuk kembali

${ }^{14}$ Polemik Calon.., Ibid.

${ }^{15}$ Polemik Calon.., Ibid.

${ }^{16}$ http:/ / nasional.tempo.co/read/news/2015/08/20/058693723/kini-pasangan-calon-wali-kotamataram-tak-tunggal, diakses tanggal 15 Januari 2016.

${ }^{17}$ Lihat Pasal 51 ayat (2) dan Pasal 52 ayat (2) UU No. 8 Tahun 2015 


\section{Lex Renaissance No. 1 VOL. 1 JANUARI 2016: 37 - 57}

dalam ketentuan Pasal 3 UU No. 8 Tahun 2015 bahwa pelaksanaan pemilihan akan dilaksanakan secara serentak yaitu pada 9 Desember 2015.

Terhadap kondisi calon tunggal tersebut dapat disimpulkan bahwa UU No. 8 Tahun 2015 dinilai kurang antisipatif dan solutif mengantisipasi permasalahan yang muncul. Hal ini dikarenakan fenomena calon tunggal justru terjadi di awal pendaftaran dan bukan pada periode verifikasi data calon kepala daerah, sebagaimana terlihat banyaknya daerah yang hingga habis masa pendaftaran tidak memenuhi jumlah minimal dua pasangan calon kepala daerah. Apabila dilakukan pembacaan terhadap ketentuan UU No. 8 Tahun 2015, maka proses pengajuan calon kepala daerah mulai dari tahapan dibukanya pendaftaran hingga habis masa pendaftaran calon kepala daerah, hanya berselang selama 3 (tiga) hari terhitung sejak pengumum pendaftaran. ${ }^{18} \mathrm{Hal}$ ini dipersulit dengan tidak ada mekanisme penambahan masa pendaftaran. Solusi perpanjangan masa pendaftaran justru datang dari Komisi Pemilihan Umum (KPU). Akan tetapi, selama masa perpanjangan pendaftaran yang dilakukan tidak menghasilkan bertambahnya calon bagi ke tiga daerah tersebut. Sedangkan aturan normatif dari Undang-Undang a quo tidak memberikan jawaban atas permasalahan yang muncul.

Menjawab kondisi demikian, KPU mengeluarkan Peraturan Komisi Pemilihan Umum No. 12 Tahun 2015 tentang Perubahan Atas Peraturan KPU No. 9 Tahun 2015 tentang Pencalonan Pemilihan Gubernur dan wakil Bupati dan Wakil Bupati, dan/atau Walikota dan Wakil Walikota. Adapun solusi yang diberikan sebagai terdapat dalam Pasal 89 PKPU No. 12 Tahun 2015 yaitu dengan memperpanjang masa pendaftaran pasangan calon paling lama 3 hari. Akan tetapi, apabila sampai berakhirnya perpanjangan masa pendaftaran hanya terdapat satu pasangan calon, maka dilakukan penundaan pemilihan dan akan diselenggarakan pada pemilihan serentak berikutnya. Apabila di dalam proses pendaftaran sudah terdapat paling sedikit 2 pasangan calon, maka dapat dilanjutkan dalam tahapan penelitian persyaratan calon. Akan tetapi, setelah dilakukan penelitian kemudian hanya terdapat satu pasangan calon yang memenuhi persyaratan atau terjadi pembatalan pasangan calon, maka ketentuan Pasal 89A dan Pasal 91 berlaku, yaitu dilakukan penundaan pemilihan kepala daerah. Penundaan pemilihan kepala daerah tersebut akan diselenggarakan pada 2017.

Pada tataran ideal, penundaan pelaksanaan pemilihan kepala daerah dikarenakan calon tunggal merupakan kemunduran terhadap pelaksanaan demokrasi dan pelanggaran hak asasi manusia. Mengingat salah satu nilai demokrasi menurut Henry B. Mayo adalah

${ }^{18}$ Lihat Pasal 44 UU No. 8 Tahun 2015 
menyelenggarakan pergantian pimpinan secara teratur (orderly succession of rulers). ${ }^{19}$ Penundaan pelaksanaan pemilihan kepala daerah mengganggu sistem peralihan kepemimpinan di daerah. Apabila pelakasanaan pemilihan kepala daerah ditunda, maka jabatan kepala daerah akan diisi oleh pelaksana tugas (PLT) dengan kewenangan terbatas. Sehingga bukan hal yang tidak mungkin semangat pembangunan di daerah akan terhambat yang kemudian dapat berujung pada tidak terpenuhinya hak warga negara. Meskipun tidak dapat kita ingkari, bahwa dalam pelaksanaan demokrasi di daerah kontestasi sangat diperlukan. Untuk itu, sangat perlu diupayakan mewujudkan demokrasi yang partisipatoris dan sejalan dengan keinginan rakyat. Sehingga partisipasi yang lebih dari masyarakat tentunya akan memberikan keseimbangan dalam proses demokrasi.

Hal ini sejalan dengan hak asasi manusia yang dilanggar dengan penundaan pelaksanaan pemilihan kepala daerah bagi daerah yang hanya memiliki satu pasangan calon. Adanya permasalahan calon tunggal yang diakibatkan oleh tidak antisipatifnya aturan normatif pemilihan kepala daerah seharusnya tidak menjadi legitimasi pemerintah untuk berbuat abuse of power, yaitu pengabaian terhadap hak-hak asasi bagi 'si calon' maupun bagi masyarakat di daerah. Hal ini dikarenakan bingkai dari penyelenggaraan negara Indonesia adalah demokrasi sebagaimana Ulf Sundhaussen menyebutkan bahwa tiga syarat demokrasi untuk suatu sistem politik, yaitu: jaminan atas hak seluruh warganegara untuk dipilih dan memilih dalam pemilu yang dilaksanakan secara berkala dan bebas. ${ }^{20}$

Penundaan dilaksanakannya pemilihan kepala daerah bagi calon tunggal di tahun 2015, dirasa menimbulkan kerugian hak konstitusional bagi warga negara. Kerugian hak konstitusional tersebut dirasakan oleh Effendi Ghazali (Pemohon I) dan Yayan Sakti Suryandaru (Pemohon II), sehingga mereka melakukan gugatan judicial review atas UU No.8 Tahun 2015. Terhadap judicial review tersebut menghasilkan Putusan MK-RI No. 100/PUU-XIII/2015 terkait pemilihan kepala daerah dengan hanya satu pasangan calon.

Pada pokok gugatannya, Effendi merasa hak konstitusional telah dilanggar berdasarkan ketentuan Pasal 28D ayat (1) dan Pasal 27 ayat (1) UUD 1945. Alasan yang diungkapkan Pemohon adalah terkait dengan jaminan perlindungan hukum dan kepastian hukum yang adil serta perlakukan yang sama di hadapan hukum, dibanding dengan warga

${ }^{19}$ Henry B. Mayo, An Introduction to Democratic Theory, Oxford Univercity Press, New York, 1960, hlm. 70, dalam Ni'matul Huda, Negara Hukum, Demokrasi dan Judicial Review, UII Press, Yogyakarta, 2005, hlm. 13.

${ }^{20}$ Ulf Sundhoussen,"Demokrasi dan Kelas Menengah: Refleksi Mengenai Pembangunan Politik, "dalam Prisma, No. 2 Tahun XXI, 1992, hlm 64 dalam R.Siti Zuhro, dkk Demokrasi Lokal; Perubahan dan Kesinambungan Nilai-Nilai Budaya Politik Lokal, Ombak, Yogyakarta, 2009, hlm. 19. 


\section{Lxx Renaissance No. 1 VOL. 1 JANUARI 2016: 37 - 57}

negara yang tinggal di daerah lain yang memiliki lebih dari satu pasangan calon serta jaminan konstitusional yaitu hak dipilih dan memilih bagi warga negara. ${ }^{21}$

Terhadap kondisi demikian, Mahkamah Konstitusi melalui putusannya memutus bahwa pasal-pasal yang dimohonkan bertentangan dengan UUD 1945. Mahkamah menimbang bahwa tidak ada keharusan pasangan calon paling sedikit 2 (dua) pasangan calon, dengan syarat sepanjang tidak dimaknai sebagai menetapkan 1 (satu) pasangan calon kepala daerah. ${ }^{22}$ Sehingga adanya calon tunggal tidak boleh dimaknai sebagai penetapan calon tunggal kepala daerah sebagai kepala daerah terpilih tanpa melalui tahapan pemilihan kepala daerah. Lebih jelasnya dalam putusan tersebut, Mahkamah menyatakan Pasal 49 ayat (9), Pasal 50 ayat (9) serta Pasal 51 ayat (2) dan Pasal 52 ayat (2) UU Pilkada bertentangan dengan UUD 1945 dan tidak memiliki kekuatan hukum mengikat sepanjang tidak dimaknai mencakup pengertian menetapkan satu pasangan calon kepala daerah. ${ }^{23}$

Berkaitan dengan mekanisme pemilihan, Mahkamah menyatakan, untuk Pilkada yang hanya diikuti oleh satu pasangan calon, manifestasi kontestasinya lebih tepat apabila dipadankan dengan plebisit yang meminta rakyat sebagai pemilih untuk menentukan pilihannya apakah "setuju" atau "tidak setuju" dengan pasangan calon tersebut. ${ }^{24}$ Sehingga masyarakat dapat menentukan, apabila jumlah suara lebih banyak menyatakan setuju kepada calon kepala daerah maka calon kepala daerah tersebut terpilih oleh masyarakat untuk memimpin daerah tersebut. Akan tetapi, apabila jumlah suara yang menyatakan tidak setuju terhadap kepala daerah lebih banyak daripada setuju maka dilakukan penundaan pemilihan kepala daerah. ${ }^{25}$

Penundaan tersebut, menurut Mahkamah tidak bertentangan dengan konstitusi. Sebab, pada dasarnya rakyat telah memutuskan penundaan itu melalui pemberian suara "tidak setuju" tersebut. ${ }^{26}$ Mekanisme itu pun dinilai Mahkamah lebih demokratis dibandingkan dengan menyatakan "menang secara aklamasi" tanpa meminta pendapat rakyat jika calon tidak memiliki pesaing. ${ }^{27}$ Mahkamah menegaskan, penekanan terhadap sifat "demokratis" menjadi substansial lantaran merupakan perintah konstitusi, dalam hal ini Pasal 18 ayat (4) UUD 1945. Dengan mekanisme demikian, amanat konstitusi yang

\footnotetext{
${ }^{21}$ Putusan Mahkamah Konstitusi Nomor 100/PUU-XIII/2015

22Putusan Mahkamah Konstitusi Nomor 100/PUU-XIII/2015

23Putusan Mahkamah Konstitusi Nomor 100/PUU-XIII/2015

${ }^{24}$ Referendum Kepala Daerah, edisi IV Juli-Agustus 2015, http://www.kpu.go.id/koleksigambar/Revisi+Final+Majalah+Suara+KPU+Edisi+4.compressed_.pdf

${ }^{25}$ Referendum Kepala Daerah, Ibid.

${ }^{26}$ Referendum Kepala Daerah, Ibid.

${ }^{27}$ Referendum Kepala Daerah, Ibid.
} 
menuntut pemenuhan hak konstitusional warga negara, dalam hal ini hak untuk dipilih dan memilih, serta amanat agar Pilkada dilaksanakan secara demokratis dapat diwujudkan. ${ }^{28}$

Dalam putusannya, Mahkamah juga menegaskan Pilkada yang hanya diikuti oleh satu pasangan calon harus ditempatkan sebagai upaya terakhir, semata-mata demi memenuhi hak konstitusional warga negara. Dengan catatan, bahwa sebelumnya penyelenggara Pemilu telah mengusahakan dengan sungguh-sungguh untuk menemukan paling sedikit dua pasangan calon. ${ }^{29}$

Melihat pendapat Mahkamah Konstitusi dapat diketahui bahwa terdapat hak-hak politik warga negara yang sedang diperjuangan tanpa mengurangi nilai demokrasi itu sendiri. Hakikat kontestasi dari suatu kompetisi atau pemilihan tidak dapat dikungkung oleh minimnya pasangan calon yang mendaftar dalam pilkada, karena pelaksanaan kedaulatan rakyat tidak disimpangi dengan sekedar menunda pilkada tahun pemilihan berikutnya. Penundaan akan berimplikasi pada tertundanya hak-hak pemilih dan mengurangi sisi demokratis pilkada. Dalam memaknai kontestasi, Mahkamah tidak sependapat dengan penerapan uncostested election seperti diterapkan di Amerika Serikat, Inggris, Kanada, dan Singapura, yang lebih identik dengan persetujuan secara aklamasi tanpa melibatkan suara rakyat. ${ }^{30}$ Makna kontestasi tidak hanya dibatasi dengan adanya pasangan calon, namun dapat juga dimanifestasikan dalam bentuk pilihan setuju atau tidak setuju. Jika calon kepala daerah dapat diterapkan sebagai kepala daerah terpilih. Namun, jika warga banyak memilih untuk tidak setuju maka pilkada ditunda pada pemilihan selanjutnya.

Model penafsiran demikan, menunjukkan adanya pergeseran paradigma Mahkamah dalam mendudukkan siapa yang dapat berkompetisi dengan pasangan calon. Itulah constitutional policy Mahkamah yang mengubah rezim pemilihan calon menjadi pilihan referendum, meski hal demikian hanya ditempatkan sebagai 'emergency exit'. Artinya pilkada dengan calon tunggal adalah upaya terakhir setelah semua tahapan penjaringan pasangan calon 'gagal' menghadirkan 2 paslon atau lebih. ${ }^{31}$

Putusan Mahkamah Konstitusi tersebut memberikan dua implikasi sekaligus terhadap sistem pilkada serentak, yaitu implikasi langsung dan implikasi tidak langsung. Implikasi langsung dari putusan MK tentang calon tunggal berupa: Pertama, adanya mekanisme baru dalam pelaksanaan pilkada serentak mendatang. Dengan diberikannya peluang bagi satu pasangan calon kepala daerah dalam mengikuti kontestasi pilkada

28Putusan Mahkamah Konstitusi Nomor 100/PUU-XIII/2015

${ }^{29}$ Putusan Mahkamah Konstitusi Nomor 100/PUU-XIII/2015

${ }^{30}$ Mohammad Mahrus Ali, "Tafsir Sistematis Untuk Pilkada Demokratis", Majalah Konstitusi, No. 104, Oktober 2015, hlm 6.

${ }^{31}$ Mohammad Mahrus Ali, "Tafsir Sistematis.., Ibid. 


\section{Lx Renaissance No. 1 VOL. 1 JANUARI 2016: 37 - 57}

serentak melalui mekanisme memilih "setuju" atau "tidak setuju", berarti adanya mekanisme baru untuk menentukan pemimpin di daerah dalam pilkada serentak. Menurut beberapa pihak, mekanisme ini disebut juga mekanisme referendum. Kendatipun demikian, menurut hakim MK Suhartoyo saat membacakan putusan MK, dia menyebutkan, pola ini tidak bertentangan dengan konstitusi lantaran masyarakat telah menyampaikan haknya melalui persetujuan atau ketidaksetujuan atas calon tunggal tersebut. ${ }^{32}$

Kedua, pengaturan melalui PKPU tentang calon tunggal. Karena pelaksanaan pemilihan dengan hanya satu pasangan calon kepala daerah maka KPU harus membuat peraturan mengenai calon tunggal. Menindaklanjuti Putusan MK No.100/PUU-XIII/2015, KPU kembali mengeluarkan Peraturan KPU No. 14 Tahun 2015 tentang Pemilihan Gubernur, dan Wakil Gubernur, Bupati, dan Wakil Bupati, dan/atau Wakil Walikota dan Wakil Walikota dengan Satu Pasangan Calon. Ketentuan tersebut, jelas mengubah peraturan KPU sebelumnya yang menghendaki dilakukan penundaan pemilihan kepala daerah dalam pilkada serentak selanjutnya yaitu terdapat mekanisme referendum.

Adapun pengaruh tidak langsung terhadap putusan Mahkamah ini berupa: Pertama, terjadinya kekosongan hukum bagi calon tunggal dalam tata pelaksanaan Pilkada dalam UU a quo. ${ }^{33}$ Di satu sisi, diakui putusan Mahkamah tersebut memberikan manfaat atas kebuntuan pilkada serentak atas calon tunggal yang menimbulkan polemik. Namun, di sisi lain, putusan tersebut menimbulkan ketidakpastian hukum yaitu berdampak secara struktural terjadinya kekosongan hukum dalam UU pilkada $a$ quo.

Kedua, kekosongan hukum pengaturan sengketa pilkada untuk calon tunggal. Peraturan Mahkamah Konstitusi (PMK) No. 1 Tahun 2015, PMK No. 2 Tahun 2015 dan PMK No. 3 Tahun 2015 merupakan sejumlah peraturan MK yang dibuat untuk memutus sengketa hasil Pilkada. Secara garis besar ketiga PMK tersebut memang dibuat dalam kondisi normal dengan pengertian pilkada yang diikuti oleh pasangan calon lebih dari satu. ${ }^{34}$ Beberapa implikasi dari putusan Mahkamah Konstitusi mengenai calon tunggal tersebut menimbulkan kekosongan hukum terkait mekanisme penyelesaian sengketa pemilihan kepala daerah terhadap daerah yang hanya memiliki satu pasangan calon. Bukan hal yang tidak mungkin apabila kehadiran calon tunggal dapat terjadi perselisihan hasil pemilihan kepala daerah. Terkait perselisihan hasil pemilihan kepala daerah diatur dalam Pasal 142

\footnotetext{
Januari 2016.

32http:// nasional.inilah.com/ Implikasi Serius MK Putuskan Calon Tunggal Pilkada, diakses tanggal 25

${ }^{33}$ Damang, "Implikasi Hukum Calon Tunggal Kepala Daerah", Opini NegaraHukum.com. diakses pada tanggal 24 Januari 2016.

${ }^{34}$ Hani Adhani, "Sengketa Pilkada Pasangan Calon Tunggal", Opini Majalab Konstitusi, N0. 105- November 2015, hlm. 7 .
} 
UU No. 8 Tahun 2015, dimana menyebutkan bahwa sengketa pemilihan terdiri atas sengketa antar peserta pemilihan dan sengketa antara peserta pemilihan dan penyelenggara pemilihan sebagai akibat dikeluarkannya Keputusan KPU Provinsi dan KPU Kabupaten/kota. Peraturan MKRI No. 4 Tahun 2015 telah mengatur hal baru terkait dengan legal standing dari pemohon dalam sengketa pemilihan kepala daerah bagi daerah yang hanya memiliki satu pasangan calon yaitu para pasangan dan juga pemantau pemilihan.

\section{Upaya untuk Mengatasi Calon Tunggal dalam Pemilihan Kepala Daerah Serentak yang Akan Datang}

Problematika terkait keberadaan calon tunggal kepala daerah yang muncul di dalam penyelenggaraan pemilihan kepala daerah serentak di 2015 seharusnya disikapi dengan segera oleh pemerintah maupun Dewan Perwakilan Rakyat pusat. Akan tetapi, sikap segera yang harus diambil tidak diperbolehkan keluar dari tata aturan yang hukum yang berlaku. Hal ini sesuai dengan Konstitusi Indonesia bahwa negara Indonesia berdasarkan atas hukum, hal ini termaktub dalam Pasal 1 ayat (3) Undang-Undang Dasar 1945. Salah satu prinsip yang menyangga tegaknya negara modern ini adalah supremasi hukum (Supremacy of Law). Oleh karena itu, hukum menjadi bingkai dalam salah satu penyelenggaraan bernegara yaitu pelaksanaan sistem ketatanegaraan di Indonesia.

Solusi terhadap fenomena calon tunggal kepala daerah dalam pemilihan kepala daerah serentak di tahun 2015, dilakukan dengan mengeluarkan Peraturan KPU No. 12 Tahun 2015 sebagaimana yang telah diuraikan dalam sub bahasan sebelumnya dapat disebut dengan istilah "kelebihan beban". Hal ini dikarenakan pengaturan tentang percepatan pemilihan kepala daerah pada 9 Desember 2015 ditentukan dalam Pasal 201 UU No. 8 Tahun 2015. Sedangkan Peraturan KPU bukanlah Peraturan Pemerintah yang melaksanakan undang-undang pemilihan kepala daerah. Peraturan KPU hanya peraturan teknis untuk melaksanakan pemilihan. ${ }^{35}$

Dari sisi kekuatan peraturan, Peraturan KPU berada di bawah undang-undang. Hal ini dikarenakan Peraturan KPU merupakan hal-hal teknis pelaksanaan undang-undang, bukan terkait hal-hal substansial yang seharusnya diatur dalam undang-undang. Sedangkan fenomena calon tunggal mengandung hal-hal substansial yang terlewat diselesaikan para legislator. Kealpaan tersebut terlihat dari tidak ditemukan satu pun rujukan pasal dan ayat hlm. 243.

${ }^{35}$ Maria Farida Indrati, Imu Perundang-undangan: Jenis Fungsi dan Materi Muatan, Kanisius, Yogyakarta, 2007, 


\section{Lx Renaissance No. 1 VOL. 1 JANUARI 2016: 37 - 57}

dalam UU No. 8 Tahun 2015 yang dapat dijadikan dasar membuat peraturan menunda pilkada.

Ketentuan yang terdapat dalam Pasal 48, Pasal 49, dan Pasal 52 UU No. 8 Tahun 2015 hanya menganjurkan penundaan dalam hitungan hari untuk masa pendaftaran pasangan calon. Kondisi demikian membuat KPU mempunyai langkah yang cepat dalam mengantisipasi persoalan yang muncul mengenai fenomena calon tunggal, akan tetapi solusi yang diberikan oleh KPU melampaui apa yang terdapat dalam undang-undang.

Peraturan KPU hanya bersifat sementara, hal ini terkait dengan jangka waktu dari peraturan KPU itu sendiri. ${ }^{36}$ Jangka waktu dari peraturan KPU hanya sampai 2017. Sedangkan fenomena calon tunggal bukan spesifik terjadi di pemilihan kepala daerah serentak 2015. Apabila kebijakan tersebut ditetapkan dalam pemilihan kepala daerah 2015 , maka pemilihan kepala daerah bercalon tunggal akan terus ditunda hingga jumlah pasangan calon memenuhi syarat dua pasangan hingga mengakibatkan tahapan di daerah tersebut akan tertinggal dari daerah lainnya.Calon tunggal tidak memenuhi syarat minimal sehingga pemilihan kepala daerah tidak dapat dilangsungkan. Secara substansi, ketentuan tersebut menegaskan bahwa persaingan atau kompetisi dalam pemilihan kepala daerah sangat penting. Kompetisi hanya bisa terjadi jika pemilihan kepala daerah diikuti sekurangkurangnya dua pasangan calon.

Hal itu sejalan dengan peringatan Elkit dan Svenson, yang mengatakan bahwa pemilihan hanya akan kompetitif jika pemilih mempunyai pilihan di antara alternatifalternatif politik yang bermakna. Lebih jauh dikatakan, secara hukum (de jure) dan kenyataan (de facto) tidak menetapkan pembatasan dalam rangka penyingkiran calon-calon atas dasar alasan politik. ${ }^{37}$ Merujuk pendapat itu, kualitas kompetisi semakin baik jika jumlah calon semakin banyak. Kompetisi bermanfaat untuk menguji dan memperkuat komitmen calon terhadap rakyat, dengan adu program dalam tahapan kampanye. Hanya melalui kompetisi rakyat dapat menilai para calon.

Ketidakadilan yang terdapat dalam Peraturan KPU memang dapat terjadi. Hal ini dikarenakan sifat dari Peraturan KPU sendiri yang hanya mengatur secara teknis. Peraturan KPU terlihat tidak mempertimbangkan perlakukan adil terhadap hak-hak dasar warga negara, yaitu hak memilih dan dipilih, hak atas perlakuan yang sama di hadapan hukum, serta hak politik dan pemerintahan bagi pasangan calon tunggal maupun bagi masyarakat di daerah yang terdapat pasangan calon tunggal. Kondisi demikian tentunya bertentangan

${ }^{36}$ Maria Farida Indrati, Ilmu Perundang..., Ibid.

${ }^{37}$ Joko J. Prihatmoko, Pemilihan Kepala Daerah Langsung: Filosofi, Sistem, dan Problema Penerapan di Indonesia, Pustaka Pelajar, Yogyakarta, 2005, hlm. 220. 
dengan perspektif negara hukum yang demokratis, bahwa prinsip-prinsip demokrasi harus ditegakkan. Di mana penghormatan terhadap hak-hak warga negara merupakan manifestasi dari proses demokrasi. Oleh karena itu, pengabaian hak-hak politik tersebut dapat menimbulkan kerugian hak-hak dasar lebih besar bagi sebagian warga negara yang bersinggungan langsung dengan adanya fenomena calon tunggal apabila solusi yang diberikan adalah penundaan pemilihan kepala daerah.Mustahil apabila menolak adanya kondisi pasangan calon tunggal kepala daerah. Hal ini berkaitan dengan masih terbuka lebar banyak siasat politik untuk sekedar memenuhi persyaratan prosedural dan atau hanya mencari kepentingan pragmatis.

Dikeluarkannya Peraturan KPU No. 12 Tahun 2015 merupakan solusi yang tidak tepat berkaitan dengan materi muatan peraturan KPU a quo yang "kelebihan beban". Maksud dari "kelebihan beban" dapat diketahui dengan melakukan kajian terhadap materi muatan dari peraturan perundang-undangan. Pasal 8 Undang-Undang No. 12 Tahun 2011 tentang Pembentukan Peraturan Perundang-undangan mengatur jenis peraturan perundangundangan selain yang disebutkan dalam Pasal 7 ayat (1). Jenis peraturan perundangundangan tersebut diakui keberadaannya dan mempunyai kekuatan hukum mengikat sepanjang diperintahkan oleh peraturan perundang-undangan yang lebih tinggi atau dibentuk berdasarkan kewenangan. Adapun peraturan yang dimaksud yakni: Peraturan yang ditetapkan oleh Majelis Permusyawaratan Rakyat, Dewan Perwakilan Rakyat, Dewan Perwakilan daerah, Mahkamah Agung, Mahkamah Konstitusi, Badan Pemeriksa keuangan, Komisi Yudisial, Bank Indonesia, Menteri, Badan, Lembaga atau Komisi yang setingkat yang dibentuk oleh undang-undang atau pemerintah atas perintah undang-undang, DPRD Provinsi, Gubernur, DPRD Kabupaten/kota, Bupati/Walikota, Kepala Desa atau yang setingkat. ${ }^{38}$ Tetapi disayangkan, UU No. 12 Tahun 2011 tidak menentukan secara pasti apa saja materi muatan dari pelbagai jenis peraturan tersebut, serta bagaimana penjenjangan atau hirarki serta kedudukan dari peraturan-peraturan tersebut terhadap peraturan yang telah ditetapkan dalam Pasal 7 ayat (1) UU No. 12 Tahun 2011.39

Jimmly Asshiddiqie berpendapat, terdapat pejabat-pejabat setingkat Menteri seperti Gubernur Bank Indonesia, Kepala kepolisian RI, Panglima Tentara Nasional Indonesia, dan Jaksa Agung, yang dapat pula diberi kewenangan regulasi. Termasuk dalam kategori ini adalah lembaga-lembaga yang bersifat independen seperti Komisi Pemilihan Umum, Komisi Nasional Hak Asasi Manusia, Komisi Penyiaran Indonesia, dan sebagainya. Badan

\footnotetext{
${ }^{38}$ Ni'matul Huda dan R. Nazriyah, Teori dan Pengujian Peraturan Perundang-undangan, Nusa Media, Bandung, 2011, hlm. 88.

${ }^{39}$ Ni'matul Huda dan R. Nazriyah, Teori dan Pengujian...,Ibid., hlm. 89.
} 


\section{Lx Renaissance No. 1 VOL. 1 JANUARI 2016: $37-57$}

atau lembaga seperti ini dapat mengeluarkan peraturan tersendiri, asalkan kewenangan regulatif itu diberikan oleh undang-undang. ${ }^{40}$ Oleh karena itu, menjadi penting payung hukum undang-undang yang diberikan kepada suatu peraturan yang dikeluarkan oleh lembaga-lembaga independen, dan tidak terkecuali kepada peraturan yang dikeluarkan oleh KPU.

Dasar mengingat Peraturan KPU tersebut salah satunya adalah UU No. 8 Tahun 2015. Akan tetapi, terhadap ketentuan mengenai adanya penundaan pelaksanaan pemilihan kepala daerah bagi daerah dengan satu pasangan calon tidak diberikan oleh undang-undang a quo. Penundaan hanya terkait memperpanjang pengajuan calon pada masa verifikasi.

Selanjutnya, ketentuan mengenai keputusan pelaksanaan pemilihan kepala daerah pada kondisi terdapat calon tunggal kepala daerah yang mengharuskan adanya penundaan tanpa diperintah oleh undang-undang di atasnya, berdampak kepada kepentingan yang mengikat secara umum maupun hak-hak masyarakat di daerah, baik itu bagi calon kepala daerah maupun bagi masyarakat di daerah dengan satu pasangan calon.Oleh karena itu, perlu dicermati kembali pendapat Soehino, bahwa salah satu materi muatan undang-undang yaitu mengikat secara umum. ${ }^{41}$ Hal tersebut dipahami pula dengan apa yang disampaikan Bagir Manan dan Kuntana Magnar, bahwa materi muatan undang-undang ditentukan salah satunya berdasarkan tolok ukur menyangkut menyangkut hak dasar atau hak asasi. ${ }^{42}$

Wacana yang kemudian muncul di media adalah desakan pemerintahan Jokowi untuk mengeluarkan Perppu untuk kondisi calon tunggal pilkada di $2015 .{ }^{43}$ Kondisi ketidakjelasan sikap pemerintah untuk mengeluarkan Perppu tersebut diramaikan dengan problematika hukum selanjutnya oleh Mahkamah Konstitusi. Mengapa demikian, sebab Mahkamah membuat norma baru sebagai jalan keluar atas kebuntuan polemik calon tunggal. Mahkamah tidak hanya membatalkan tetapi juga memberi norma yang sebelumnya tidak ada. Terlebih putusan tersebut hanya ditindaklanjuti dengan Peraturan Komisi Pemilihan Umum (PKPU). Dibandingkan dengan pengaturan calon lain yang bukan calon tunggal dengan menggunakan UU tentunya PKPU ini tidak setingkat dengan UU. Sebagaimana sifat dari Putusan Mahkamah Konstitusi yaitu final dan mengikat. Dalam fungsinya sebagai guardian of constitution, MK berada di garis “negative legislator". Akan tetapi, terhadap Putusan MK No. 100/PUU-XIII/2015 MK telah melakukan pembentukan

40 Jimmly Asshiddiqie, Peribal Undang-Undang, Konstitusi Press, Jakarta, 2006, hlm 210-211 dalam Ni'matul Huda dan R. Nazriyah, Teori dan Pengujian..., Ibid., hlm. 90.

${ }^{41}$ Ni'matul Huda dan R. Nazriyah, Teori dan Pengujian.., Ibid., hlm. 97.

${ }^{42} \mathrm{Ni}$ 'matul Huda dan R. Nazriyah, Teori dan Pengujian.., Ibid.

${ }^{43}$ http://www.cnnindonesia.com/politik/20150801152121-32-69486/pdip-perppu-jadi-solusi-terakhircalon-tunggal-di-pilkada/, diakses tanggal 25 Januari 2016. 
norma baru yaitu, calon tunggal harus dikontestasikan secara plebisit, yaitu pemilih setuju atau tidak setuju.

Di satu sisi, ketentuan mengenai konstitusional bersyarat bagi calon tunggal yang harus dikontestasikan, pada dasarnya dapat mempengaruhi atau berimplikasi terhadap ketentuan hukum lainnya yang terkait dengan tata laksana penyelenggaran pemilihan kepala daerah. Hal inilah menjadi salah satu kelemahan dari Putusan MK yang selalu menyatakan suatu pasal sebagai konstitusional bersyarat. Perubahan terhadap satu ketentuan akan menyebabkan ketentuan lainnya rentan mengalami ketidakharmonisan antar ketentuan, termasuk memicu akan terjadinya kekosongan hukum dalam perundang-undangan tersebut. Implikasi hukum yang pasti terjadi, akibat Putusan MK terkait calon tunggal kepala daerah, paling mendasar dalam UU Pilkada terletak pada keadaan UU a quo mengalami kekosongan hukum bagi calon tunggal dalam tata laksana Pilkada.

Sehingga seharusnya penerbitan Perppu lebih tepat, Perppu bisa hadir menjawab persoalan ini secara cepat. Perppu ini akan jadi mekanisme proteksi untuk melindungi hak konstitusional pemilih dan calon atas pilkada yang jujur, adil, dan demokratis. ${ }^{44}$ Sebab akan lebih memberikan jaminan hukum yang kuat. Namun apa boleh buat, nasi sudah menjadi bubur, putusan MK sudah dikeluarkan dan pilkada serentak pun sudah dilaksanakan, tindakan hukum yang harus segera dilaksanakan adalah merevisi UU a quo dengan mengakomodir seluruh ketentuan dalam putusan MK tersebut.

\section{Gagasan Revisi UU Nomor 8 Tahun 2015 untuk Pemilihan Kepala Daerah Serentak yang Akan Datang}

Pemilihan kepala daerah serentak tidak hanya terjadi pada 2015 saja. Akan tetapi akan secara berkesinambungan dilaksanakan pada tahun-tahun berikutnya. Oleh karena itu, perlu diambil langkah untuk mengatasi calon tunggal kepala daerah yang akan datang dengan solusi yang berorientasi jangka panjang. Di satu sisi Mahkamah Konstitusi melalui Putusan MK No. 100/PUU-XIII/2015 telah memberikan 'lampu hijau' adanya calon tunggal kepala daerah dalam pilkada. Oleh karena itu, menjadi hal yang mendesak diperlukan langkah yang cepat untuk menindaklanjuti tidak terkondifikasinya dan tidak terintegrasi aturan mengenai calon tunggal kepala daerah. Solusi yang dapat diambil adalah dengan melakukan revisi UU No. 8 Tahun 2015. Januari 2016.

${ }^{44}$ Anggraini, "Calon Tunggal Versus Bumbung Kosong”, Opini Sindonews.com, diakses pada tanggal 22 


\section{Lx Renaissance No. 1 VOL. 1 JANUARI 2016: 37 - 57}

Adapun ketentuan yang perlu diatur dalam gagasan revisi UU No. 8 Tahun 2015 adalah memasukkan kondisi bahwa apabila setelah diupayakan untuk dipenuhi sekurangkurangnya dua calon kepala daerah, maka terhadap daerah yang hanya memiliki satu pasangan calon kepala daerah dapat melanjutkan proses demokrasi lokal yaitu pemilihan kepala daerah. Ketentuan lain terkait mekanisme kampanye, pemungutan suara, dan, perselisihan sengketa hasil pemilihan kepala daerah juga harus diatur dalam undangundang.

Di samping aturan mengenai calon tunggal kepala daerah, penting untuk memasukkan aturan yang dapat dijadikan langkah preventif dalam mengatasi calon tunggal kepala daerah. Aturan tersebut mengenai ambang batas perolehan suara yang diperoleh partai politik maupun memasukkan revisi mengenai ambang batas jumlah dukungan suara bagi calon perseorangan yang juga telah diputuskan oleh Mahkamah Konstitusi dalam Putusan MK No.60/PUU-XIII/2015. Syarat bagi partai politik maupun gabungan partai politik untuk mengajukan calon kepala daerah diatur dalam ketentuan Pasal 40 UU No. 8 tahun 2015. Dalam ketentuan tersebut mengatur jumlah persentase akumulasi perolehan suara sah dalam pemilihan umum kepala daerah yang memiliki kursi di dewan.

Di satu sisi, pendaftaran calon kepala daerah melalui jalur perseorangan diatur dalam ketetentuan Pasal 41 UU No. 8 Tahun 2015. Apabila mencermati ketentuan persentase jumlah suara sah yang harus dimiliki oleh partai politik atau gabungan partai politik dalam mengajukan calon kepala daerah terjadi peningkatan jumlah daripada pengaturan mengenai syarat pengajuan calon di dalam undang-undang sebelumnya, yaitu di dalam Undang-Undang No. 32 Tahun 2004. Naiknya syarat dukungan calon yang diusung partai politik yaitu memiliki sekurang-kurangnya 20\% kursi DPRD atau 25\% suara sah hasil pemilu terakhir. Hal ini membuat koalisi partai mengusung calon menjadi lebih alot dan rumit. Sebelumnya, syarat dukungan hanya 15\% kursi DPRD atau 15\% suara sah hasil pemilu terakhir. ${ }^{45}$

Di satu sisi, partai politik sebagai salah satu pilar demokrasi di Indonesia mempunyai fungsi salah satunya adalah rekrutmen politik. Menurut Miriam Budiardjo, fungsi partai politik diantaranya adalah sarana komunikasi politik, sosialisasi politik (political socialization), sarana rekrutmen politik, dan pengatur politik. ${ }^{46}$ Berdasarkan UndangUndang No. 2 Tahun 2008 tentang Partai Politik, disebutkan fungsi-fungsi partai politik dalam Pasal 11 ayat (1) diantaranya adalah sebagai rekrutmen politik dalam proses

${ }^{45}$ Lihat UU No. 32 Tahun 2004 tentang Pemerintahan Daerah

46 Miriam Budiardjo, Pengantar Ilmu Politik, Gramedia, Jakarta, 2000, hlm. 163-164. 
pengisian jabatan politik melalui mekanisme demokrasi dengan memperhatikan kesetaraan dan keadilan gender.

Partai politik sebagai representasi dari aspirasi masyarakat diberikan hak khusus yaitu dalam pengajuan calon kepala daerah. Partai Politik mempunyai kewajiban mengajukan pasangan calon karena mereka mempunyai suara dan kursi. Selain itu, partai politik adalah institusi yang sah dan legitimate untuk mengajukan pasangan calon dalam pemilihan kepala daerah. Oleh karena itu, tanggung jawab partai politik untuk menyediakan kandidat-kandidat untuk mengisi jabatan publik seharusnya menjadi agenda utama dalam kegiatan partai.

Hal serupa juga terjadi pada calon perseorangan, dimana terjadi kenaikan sebesar lebih dari $100 \%$, yang pada awalnya sebesar 3\% menjadi 6,5\%. ${ }^{47}$ Jumlah tersebut dirasa cukup berat dikarenakan terjadi peningkatan jumlah dukungan yang harus dikumpulkan terutama oleh perseorangan apabila hendak mengajukan diri sebagai calon tunggal kepala daerah. Oleh karena itu, terdapat Putusan MK No. 60/PUU-XIII/2015 mengenai calon perseorangan yang menyatakan bahwa ketentuan pasal tersebut inkonstitusional dikarenakan menghambat seseorang untuk memenuhi hak dipilih dalam pemilihan kepala daerah. Ketentuan-ketentuan yang tidak terintegrasi tersebut menjadi urgent untuk dimasukkan dalam gagasan revisi Undang-Undang No. 8 Tahun 2015 tentang Pemilihan Gubernur, Bupati, Dan Walikota sehingga dapat menjadi pedoman penyelenggaraan demokrasi lokal yang akan datang.

Besar harapan dengan dilakukan revisi UU No. 8 Tahun 2015 secara serius dan menghindari adanya kepentingan pribadi maupun golongan, penulisoptimis terhadap masa depan demokrasi di Indonesia. Sikap optimis tersebut didasarkan dalam praktek penyelenggaraan negara sesuai dengan konsep demokrasi dan mengedepankan hak-hak masyarakat. Fenomena calon tunggal kepala daerah bukan merupakan permasalahan yang tidak berujung, akan tetapi membutuhkan penanganan cepat sehingga berbagai permasalahan dapat segara diatasi.

\section{Penutup}

Berdasarkan uraian pembahasan sebelumnya, maka dapat ditarik kesimpulan , Pertama, bahwa problematika hukum calon tunggal kepala daerah dalam pemilihan kepala daerah serentak di 2015 dilatarbelakangi oleh kealpaan proses legislasi Undang-Undang No. 
8 Tahun 2015 terhadap munculnya fenomena calon tunggal kepala daerah di beberapa daerah. Undang-undang Pilkada menghendaki bahwa pemilihan kepala daerah memiliki minimal dua pasangan calon di masing-masing daerah. Akan tetapi, secara das sein terdapat tiga daerah yang pada akhir masa perpanjangan pendaftaran hanya memiliki satu pasangan calon kepala daerah. Terhadap kondisi demikian muncul solusi calon tunggal yang berasal dari KPU dengan dikeluarkannya Peraturan Komisi Pemilihan Umum No. 12 Tahun 2015 yang berisi penundaan pelaksanaan pemilihan bagi daerah yang hanya memiliki satu pasangan calon. Atas kondisi tersebut, Putusan MK No. 100/PUU-XIII/2015 memberikan solusi daerah-daerah dengan calon tunggal tetap dapat melaksanakan Pilkada agar hak konstitusional masyarakat di daerah tersebut tidak menjadi hilang. Kedua, solusi jangka pendek yang tepat mengatasi calon tunggal kepala daerah di 2015 adalah dikeluarkannya Peraturan Pemerintah Pengganti Undang-Undang (Perppu), sedangkan solusi jangka panjang adalah segera melakukan revisi UU No. 8 Tahun 2015.

\section{Daftar Pustaka}

Adhani, Hani, Sengketa Pilkada Pasangan Calon Tunggal, Opini Majalah Konstitusi, N0. 105- November 2015.

Anggraini, Calon Tunggal Versus Bumbung Kosong, Opini Sindonews.com.

Budiardjo, Miriam, Pengantar Ilmu Politik, Gramedia, Jakarta, 2000.

Calon Tunggal, Perppu dan Kekosongan Hukum, Suara Komisi Pemilihan Umum, edisi IV Juli-Agustus 2015, http://www.kpu.go.id/koleksigambar/Revisi+Final+Majalah +Suara+KPU+Edisi+4.compressed_.pdf

Damang, Implikasi Hukum Calon Tunggal Kepala Daerah, Opini NegaraHukum.com.

FaridaIndrati, Maria, Ilmu Perundang-undangan: Jenis Fungsi dan Materi Muatan, Kanisius, Yogyakarta, 2007.

Huda, Ni'matul, Negara Hukum, Demokrasi dan Judicial Review, FH UII Press, Yogyakarta, 2005.

dan R. Nazriyah, Teori dan Pengujian Peraturan Perundang-undangan, Nusa Media, Bandung, 2011.

Dinamika Ketatanegaraan Indonesia dalam Putusan Mahkamah Konstitusi, FH UII Press, Yogyakarta, 2011.

J. Prihatmoko, Joko, Pemilihan Kepala Daerah Langsung: Filosofi, Sistem, dan Problema Penerapan di Indonesia, Pustaka Pelajar, Yogyakarta, 2005.

Mahrus Ali, Mohammad, Tafsir Sistematis Untuk Pilkada Demokratis, Majalah Konstitusi, No.104, Oktober 2015

Siti Zuhro, R., dkk, Demokrasi Lokal; Perubahan dan Kesinambungan Nilai-Nilai Budaya Politik Lokal, Ombak, Yogyakarta, 2009. 
Referendum Kepala Daerah, edisi IV Juli-Agustus 2015, http://www.kpu.go.id/koleksigambar/Revisi+Final+Majalah+Suara+KPU+Edisi+ 4.compressed_.pdf

http://www.bbc.com/indonesia/berita_indonesia/2015/08/150812_indonesia_kpu_tunda http://print.kompas.com/baca/2015/09/30/Kejar-Pilkada-2015\%2c-Tiga-Kabupatendengan-Calon-Tunggal.

Mahkamah Konstitusi, www.mahkamahkonstitusi.go.id

Antisipasi Calon Tunggal, KPU Perpanjang Waktu Pendaftaran Calon Pilkada, www.voaindonesia.com.

Polemik Calon Tungal Pilkada Serentak, Kompas Print, 23 Agustus 2015.

http://nasional.tempo.co/read/news/2015/08/20/058693723/kini-pasangan-calon-walikota-mataram-tak-tunggal,

http://nasional.inilah.com/ Implikasi Serius MK Putuskan Calon Tunggal Pilkada

Undang-Undang DasarNegara Republik Indonesia 1945

Undang-Undang No. 8 Tahun 2015 tentang Pemilihan Gubernur, Bupati, Dan Walikota

Undang-Undang Nomor 12 Tahun 2008 tentang Partai Politik

Putusan Mahkamah Konstitusi No. 100/PUU/VIII/2015

Putusan Mahkamah Konstitusi No. 60/PUU-XIII/2015

Putusan Mahkamah Konstitusi No. 42/PUU-XIII/2015

Peraturan Mahkamah Konstitusi Nomor 6 Tahun 2015

Peraturan KPU No. 12 Tahun 2015

Peraturan KPU No. 14 Tahun 2015 